\title{
CORLHNS News
}

\section{ENT UK Spring Meeting}

o The CORLHNS is happy to announce the ENT UK is organising the ENT UK Spring Meeting in London on the 8th of April 2022. The current president of ENT UK, Professor Nirmal Kumar has been very kind in arranging a sponsorship for 5 trainees to attend the above-mentioned meeting by ENT UK.

o It will be a hybrid event taking place at the Royal College of Surgeons in London and will be livestreamed on the Medall platform. The meeting will have the highlight of the induction of the new President of ENTUK. The discussions will revolve around various topics of interest in the ENT field, among which:

- Sustainable healthcare in ENT with Prof. Mahmood Bhutta

- Trans orbital approaches to the Skull Base with Prof. Darlene Lubbe

- Transoral microsurgery of advanced tumours of the larynx with Prof. Dr. Manuel Bernal Sprekelsen

- Celebrating diversity in ENT

o You can also view more information about the meeting at the following link: https://www.entuk.org/events/1468 .

\section{Annual BSO Meeting}

o The ENT UK will also be hosting the Annual BSO Meeting on the $5^{\text {th }}$ of May 2022 and registrations will be open shortly.

We wish to show our sincere appreciation to the outgoing President of ENT UK, Prof. Nirmal Kumar for the services he has rendered to uplift the ENT training standards in Sri Lanka by offering us10 placements in BACO 2020 and the Spring meeting 2022. We wish him well in his future endeavours. The CORLHNS kindly invites the membership to be a part of the above events.

This is an open access article distributed under the Creative Commons Attribution License (CC BY 4.0) (c) () $\underset{\mathrm{EY}}{ }$ This license lets others distribute, remix, tweak, and build upon the work, even commercially, as long as they credit the original author for the creation. 